\title{
Exploring The L2 Motivational Self System Of Chinese English Language Learners
}

\author{
Wang Zhe, Azizah Rajab, Hamdan Said, Masdinah Alauyah Md Yusof
}

\begin{abstract}
L2 motivation research has witnessed great development during recent decades. To re-conceptualize, the 'integrativeness' of the traditional socio-educational model, Dörnyei (2005) proposed the L2 motivational self system for better understanding and predicting $L 2$ motivation. Therefore, the theory of Dornyei's L2 Motivational Self System was employed to investigate the English learning motivation of $\mathrm{L2}$ learners in China context by conducting a qualitative study. The data were collected from eight Chinese university students by semi-structured interviews. It revealed that the ideal $L 2$ self, ought-to L2 self and L2 learning experience all contributed to the intended learning efforts of $\mathrm{L} 2$ learners. Overall, the current study provided empirical and qualitative evidence to support the construct of Dörnyei's L2 Motivational Self System in China context.
\end{abstract}

Index Terms: Motivation, Ideal L2 Self, L2 Motivational Self System.

\section{INTRODUCTION}

In the field of second language acquisition, motivation is regarded as one of the contradictory concepts due to its multidimensional characteristics. Gardner and Lambert (1, 2) initiated L2 motivation research in the field of second language acquisition which led to unprecedented changes consequently. For decades, L2 motivation research has generally been overshadowed by Gardner's socioeducational model $(2,3)$, in which integrativeness plays as the most powerful factor in L2 achievement (4, 5). However, the researchers have gradually realized that L2 motivation could not be interpreted properly in terms of the instrumental/integrative dichotomy but a complex, multifaceted structure (6). To meet the demand of reconceptualizing of L2 motivation, Dörnyei $(7,8)$ proposed L2 motivational self system which re-conceptualized 'integrativeness' of L2 motivation from self-perspective. According to Dörnyei $(8,9)$, L2 motivational self system is comprised of three main dimensions, namely, the ideal L2 self, the ought-to L2 self, and L2 learning experience. A great number of empirical studies have conducted in order to validate Dörnyei's $(7,8)$ L2 motivational self system in different linguistic and cultural contexts $(5,10,11)$. However, it has been argued that more qualitative research is required to identify and elaborate the understanding of L2 motivation self system in various contexts (12-15). On the

Revised Manuscript Received on April 19, 2019.

Wang Zhe, School of Education, Faculty of Social Sciences and Humanities Universiti Teknologi Malaysia, (Email: louisawang2016@gmail.com)

Azizah Rajab, Language Academy, Faculty of Social Sciences and Humanities Universiti Teknologi Malaysia, (Email: azizah@utm.my)

Hamdan Said, School of Education, Faculty of Social Sciences and Humanities Universiti Teknologi Malaysia, (Email: p-hamdan@utm.my)

Masdinah Alauyah Md Yusof, Language Academy, Faculty of Social Sciences and Humanities Universiti Teknologi Malaysia, (Email alauyah@utm.my) other hand, the majority of L2 motivation studies in China have employed the social-educational framework by Gardner (3) concerning whether Chinese English learners were integratively or instrumentally oriented. There is comparatively few research conducted based on Dörnyei's $(7,8)$ L2 motivational self system concerning L2 motivation among Chinese learners of English in China context. This paper fills this gap by elaborating the profile of L2 learning motivation among Chinese learners of English in China by the a qualitative study, adopting the framework of Dörnyei's $(7,8)$ L2 motivational self system.

\section{REVIEW OF LITERATURE}

Motivation has been the focus of the research of second language acquisition for decades. It provides the primary impetus to initiate L2 learning and later the driving force to sustain the long and tedious learning process; indeed, all the other factors involved in second language acquisition presuppose motivation to some extent (7). L2 learners might be frequently demotivated and "the common experience would seem to be motivational flux rather than stability" (16). In such situations, sustaining efforts and motivation during and across various educational periods seem to have a pivotal role in the learners' success in mastering a second language.

For decades, L2 motivation research has been conducted mainly based on the social-educational model proposed by Gardner and his associations in Canada $(2,3)$. Accordingly, integrative motivation maintains the central position as the most influential factor of L2 achievement and integrativeness is defined as the central factor of socialeducational model, referring to the desire to assimilate and mix with the target language community and their culture $(2,3)$.

Despite the predominance of the concept of integrativeness in L2 motivation research, many researchers argued that the concept of 'integrativeness' which is a central component of socio-psychological research representing the desire to identify and mix with Englishspeaking people and their culture (Gardner, (3) became invalid in many languages learning environments outside of the Canadian context where it had originated (17-19). Furthermore, due to the spread of globalization, the rise of the growing status of English as a global language (20) and an international lingua franca (21) makes it difficult to explain the motivation for learning English as a process of identification with a specific linguistic and cultural 
community. The lack of identification with native speakers of English was empirically demonstrated in a variety of contexts (22-24).

Thus, there is a growing need for the re-conceptualization of integrativeness so that it could become feasible in globalization context $(7,25,26)$. Consequently, Dörnyei ( 7 , 8) proposed the L2 motivational self system by synthesizing two theoretical paradigms in psychology field, which are self-discrepancy theory (27) and possible selves (28), paradigms from L2 motivation research $(29,30)$ and his own empirical research. According to Dörnyei (7), there are three main dimensions within the new and comprehensive framework, namely, the ideal L2 self, the ought-to L2 self, and the L2 learning experience:

1. "Ideal L2 Self, which is the L2-specific facet of one's 'ideal self': if the person would like to become speaks an L2, the 'ideal L2 self' is a powerful motivator to learn the L2 because of the desire to reduce the discrepancy between our actual and ideal selves. Traditional integrative and internalised instrumental motives would typically belong to

2. ii. "Ought-to L2 Self, which concerns the attributes that one believes one ought to possess to meet expectations and to avoid possible negative outcomes. This dimension corresponds to Higgins's ought self and thus to the more extrinsic (i.e. less internalised) types of instrumental motives."

3. iii. "L2 Learning Experience, which concerns situated, 'executive' motives related to the immediate learning environment and experience (e.g. the impact of the teacher, the curriculum, the peer group, the experience of success). This component is conceptualised at a different level from the two self-guides and future research will hopefully elaborate on the self-aspects of this bottom-up process."

Within the framework of L2 motivational self system (7, 8 ), motivation is the result of one's wish to reduce the discrepancy between one's ideal self (i.e., one's image of what one would like to become) and one's actual self (i.e., one's actual self-state). From the self-perspective, the concept of 'integrativeness' could be interpreted as the L2specific facet of one's ideal self.

Dörnyei's $(7,8)$ L2 motivational self system has been empirically tested and validated in a variety of contexts (5, 11,31-34). All the empirical research supported the validity of this theoretical framework in different linguistic and cultural contexts.

In China, the majority of the L2 motivation studies have been conducted based on Gardner's (3) social-educational model and they mainly concerned whether Chinese English learners were instrumentally or integratively motivated. Until now, there is still a lack of empirical research which employed the framework of L2 motivational self system on Chinese English learners in China or in other contexts. Using a qualitative approach, the current study aims to explore the profile of L2 motivation among Chinese English learners using the L2 motivational self system as its theoretical framework. It also attempts to identify the detailed and context-situated experience of the Chinese English learners in China where English language is used as a foreign language. this component."

\section{METHODOLOGY}

A qualitative method was adopted to promote a research design with flexibility, allowing an open investigation of the participants' experiences from an emic dimension (35). Thus, in order to understand the participants' individual experience, characters and innovative ideas on their English learning motivation, the qualitative approach was adopted in the current study.

\section{A. Participants}

Dörnyei states that "a well-designed qualitative study usually requires a relatively small number of respondents to yield the saturated and rich data that is needed to understand even subtle meanings in the phenomenon under focus" (35). The purposive sampling method was adopted to recruit the participants in the current study (35). Twenty students who have good performance in the English classroom and potential in learning English were recommended by their English teachers. Among them, eight students showed their willingness to participate in the interview to share their experiences of learning English. Interview participants included both male and female students that belonged to different academic fields and the year of study in a public university in southern China.

\section{B. Data Collection}

The semi-structured interviews were adopted to collect qualitative data. The participants were informed about the research purpose and the confidentiality of the interviews in advance. The participants were also given an interview preparation guide to help them to prepare for the interviews. The interviews were conducted on campus in the Chinese language so that the participants would felt at ease to elaborate their opinions in their mother language. During the interviews, the researcher asked a set of questions based on the interview guide and the average length of an interview was approximately fifteen to thirty minutes. All interviews were audio-recorded with the explicit consent of the participants.

\section{Data Analysis}

Initially, the interview recordings were transcribed into transcriptions and conducted forward and backward translation by an English lecturer working in a public university in China and a doctoral student in TESL programme in a public university in Malaysia. They translated the transcriptions independently. The lecturer translated them from English into Chinese and the doctoral student translated the Chinese version back into English. They discussed and modified until they had an agreed translation version.

Once this process was completed, the software Nvivo 9 together with manual coding were adopted to code and make connections between the themes and categories in order to understand the details of the qualitative data (36). The qualitative data were analyzed followed the steps: coding and organizing for themes, looking for patterns making 
interpretations and building theory (37).

\section{RESULTS}

The findings of the study were presented in three aspects based on Dörnyei's $(7,8)$ L2 motivational self system.

\section{A. The Ideal L2 Self}

All participants seemed to possess a clear and elaborate vision of ideal selves. Most of them have associated with their future studies or career with English learning. For an instant, some participants have plans to pursue higher education (M Phil and Ph.D.) after their bachelor's degrees.

When one participant asked about her further goals associated with English language learning, she remarked, "I will definitely take part in the entrance examination for Master program in a better university in the future. English is one of the compulsory courses, which means English proficiency is essential for the fulfillment of my dream." In addition, other participants have the aspiration to work in a foreign company or even study and live abroad. They have a clear awareness of the necessity and significance of English language learning for their further studies and career. Comparatively, they have a stronger desire to improve their English proficiency. For instance, one participant stated,

I have the plan to pursue higher education in an Englishspeaking country such as Australia or the USA. Therefore, that is why I have a stronger motivation to learn English well and get myself prepared for IELTS and TOEFL as well.

Similarly, other participants connect English learning with further benefits at the workplace. One participant explains his pursuit as following:

In the future, I will try to work in a foreign company that may offer me a higher salary and more opportunities. Probably, I will work aboard and interact with foreign clients and English definitely is used as a communication tool.

Aside from professional goals and plans, some participants shared their social goals as part of their ideal selves. When one participant was asked about how she hope or imagine herself using English in the future, she replied,

As known to all, there is an increasing number of foreigners in China nowadays with the purpose of traveling, studying or working. I would like to make more friends from different countries and communicate with them in English in the future. On the other hand, I will also try to help foreign friends living in China.

\section{B. The Ought-to Self}

The analysis of the qualitative data revealed that all participants seemed to embrace strong ought-to L2 selves which can shape their future career and life. When one was asked what disadvantages one might have to face if he did not learn English well, one participant stated, "I am afraid of being fall behind from my peers if I fail to learn English well. In addition, as I plan to find a well-paid job in a foreign company, I might not perform well in job interviews if I could not speak English very fluently." In other words, the participant tries to avoid negative consequences which demonstrate the prevention of the ought-to L2 self.

External influences from significant others such as parents, family, and friends also contribute to the participants' ought-to L2 self. All the participants agreed that their parents strongly supported them to put time and efforts on learning English continuously. In the current education system in China, the English language has been designated as a compulsory course from secondary schools to universities ever since 1978 (38). The expectation from parents has also enabled the participants to devote time and efforts into the English language study. One participant elaborates her parents' expectation in relation to her English learning as:

Generally speaking, we have to pass tests named college English band 4 and band 6 during the time of university. While my parents hope that I could perform better than that. Furthermore, they hope I can improve my practical usage of English rather than just pass the examination. They think it is required to learn English in the current society in China and if I could not learn English well, I may fall behind.

Such statement exemplified that the role of significant others in featuring ought-to L2 self. It also revealed the importance of learning English in China where parents pushed their children to learn it well. Majority of the participants all agreed that their parents would be disappointed with them if they failed to have sufficient skills of English that might result in less competitiveness at the job markets.

\section{C.L2 Learning Experience}

Based on the qualitative data analysis, the participants appear to be satisfied with their overall experiences of learning English. According to the self-reports of the participants, most of them have been learning English for more than ten years and some of them have even started learning English as early as four or five years old. This phenomenon exemplifies the significant role of English language education in China. On the successful experience of learning English, one participant shares his story,

I came across a foreigner when I was at Guangzhou international airport. Initially, I started the conversation with him in English and it was the first time for me to have communication with foreigners outside the classroom. With my broken spoken English and some gestures, we managed to understand each other. I was greatly motivated by this delighted and exciting experience and I become more confident in communication in English later on.

This above quotation revealed the satisfaction and excitement of this participant communicating in English with people from other countries. It also demonstrated that successful experience of learning English contributed strongly to the participant's intended learning effort, which is in line with the theory of Dörnyei's $(7,8)$ L2 motivational self system.

Nevertheless, there were some other participants suffering from frustrating experience of learning English. One of the participants stated,

It is difficult for me to memorize English vocabulary. When I was in middle school, I tried very hard to memorize new vocabulary and reviewed them many times every day. 
However, I forgot them very quickly, which frustrated me so much.

This above statement also demonstrated the significant role of the learning experience for the L2 learners in contrast. Most often, within the examination-oriented education system in China, Chinese English learners are less likely to feel the enjoyment and pleasure during the English learning process inside the classrooms.

\section{CONCLUSION}

This research provides some significant findings to the research on L2 motivation. First, it illustrated the details of the ideal L2 self, the ought-to L2 self, and the L2 learning experience among the interviewed L2 learners at tertiary education level in China. In this particular study, the ideal L2 self exerted a critical influence on the ideas and future plans of the L2 learners. In addition, the findings demonstrated that the ought-to L2 self moderately contributed to intended learning efforts of the L2 learners, which is in line with the results of previous studies in Asian contexts $(11,33)$. Regarding of L2 learning experience, it also confirmed that L2 learning experience has an important influence on English learning motivation of the L2 learners. The contribution of this research lies in the description on the complex and detailed picture of the learning motivation of Chinese English learners. Overall, the findings of the current study empirically supported the framework of Dörnyei's $(7,8)$ L2 motivational self-system by qualitative data.

However, there are a few limitations within the current study. Firstly, the interviews were conducted at one public university only. Therefore, it could not provide data of participants with diverse background. Secondly, the qualitative data relied on self-report of the participants which undermined the possibility of a triangulation of the data. However, the research had enabled the participants to express themselves freely about their goals and motivation on English learning.

As a conclusion, for the L2 learners themselves, it is suggested that they could build strong language learning images to promote their ideal L2 selves. Furthermore, for the English language instructors and educators, it is recommended that they could provide intervention or training program to help the English language learners in developing their future selves.

\section{REFERENCE}

1. Gardner RC, Lambert WE. Motivational variables in second-language acquisition. Canadian Journal of Experimental Psychology. 1959;13:266-72.

2. Gardner RC, Lambert WE. Attitudes and motivation in second language learning: Newbury House.; 1972.

3. Gardner RC. Social psychology and second language learning: The role of attitudes and motivation: London: Edward Arnold; 1985.

4. MacIntyre PD, MacKinnon SP, Clément R. The baby, the bathwater, and the future of language learning motivation research. Motivation, Language Identity and the L2 Self2009. p. 43-65.

5. Ryan S. Self and identity in L2 motivation in Japan: The ideal L2 self and Japanese learners of English. In: Do“rnyei Z, Ushioda E, editors. Motivation, language identity and the L2 self: Multilingual Matters, Clevedon; 2009. p. 120-43.

6. Dörnyei Z, Ushioda E. Motivation, language identity and the L2 self: Multilingual Matters; 2009.

7. Dörnyei. The psychology of the language learner: Individual differences in second language: Mahwah, $\mathrm{NJ}$ : Lawrence Erlbaum; 2005.

8. Dörnyei Z. The L2 motivational self system. In Z Dörnyei and E. Ushioda (eds.), Motivation, Language Identity and the L2 self. Bristol: Multilingual Matters; 2009. p. 9-42.

9. Csizér K, Dörnyei Z. Language learners' motivational profiles and their motivated learning behavior. Language Learning. 2005;55(4):613-59.

10. Al-Shehri AS. Motivation and vision: The relation between the ideal L2 self, imagination and visual style. In: Dörnyei and E. Ushiod, editor. Motivation, Language Identity and the L2 Self Bristol: Multilingual Matters; 2009. p. 164-71.

11. Taguchi T, Magid M, Papi M. The L2 motivational self system among Japanese, Chinese and Iranian learners of English: A comparative study. In: Dörnyei Z, Ushioda E, editors. Motivation, language identity and the L2 self. 36: Multilingual Matters, Clevedon; 2009. p. 66-97.

12. Hoyle RH, Sherrill MR. Future orientation in the selfsystem: Possible selves, self-regulation, and behavior. Journal of personality. 2006;74(6):1673-96.

13. Ushioda E, Dörnyei Z. Motivation, language identities and the L2 self: A theoretical overview. Motivation, Language Identity and the L2 Self2009. p. 1-8.

14. Gass SM, Mackey A. The Routledge handbook of second language acquisition: Routledge; 2013

15. Mercer S. Self-concept: Situating the self. Psychology for language learning: Springer; 2012. p. 10-25.

16. Ushioda E. The role of motivation: Authentik; 1996.

17. Crookes G, Schmidt RW. Motivation: Reopening the research agenda. Language learning. 1991;41(4):469512.

18. Dornyei Z, Csizér K, Németh N. Motivational dynamics, language attitudes and language globalization: a Hungarian perspective. Clevedon, UK: Multilingual Matters. 2006.

19. Dörnyei Z, Csizér K, Németh N. Motivation, language attitudes and globalisation: A Hungarian Perspective: Multilingual Matters; 2006.

20. Crystal D. English as a Global Language. Cambridge University Press; 2003.

21. Jenkins J. English as a Lingua Franca: Attitude and Identity: Oxford University Press. 2007.

22. 22. Lamb $M$. Integrative motivation in a globalizing world Systems. 2004;32:3-19.

23. Warden CA, Lin HJ. Existence of integrative motivation in an Asian EFL setting. Foreign language annals. 2000;33(5):535-45.

24. Yashima T. Orientations and motivation in foreign language learning: A study of Japanese college students. 2000.

25. Dörnyei Z, Csizér K. Some dynamics of language attitudes and motivation: Results of a longitudinal nationwide survey. Applied linguistics. 2002;23(4):42162.

26. Dörnyei Z, Ushioda E. Teaching and researching motivation. 2nd ed2011.

27. Higgins ET. Self-discrepancy: a theory relating self and affect. Psychological review. 1987;94(3):319.

28. Markus H, Nurius P. Possible selves. American Psychologist. 1986;41(9):954-69. 
29. Noels KA. Learning Spanish as a second language: Learners' orientations and perceptions of their teachers' communication style. Language Learning. 2003;53(S1):97-136.

30. Ushioda E. Ema Ushioda Trinity College Dublin, Ireland Language Learning At University: Exploring The Role Of Motivational Thinking. Motivation and second language acquisition. 2001;23.

31. Csizér K, Kormos J. Learning experiences, selves and motivated learning behaviour: A comparative analysis of structural models for Hungarian secondary and university learners of English. Motivation, language identity and the L2 self. 2009:98-119.

32. Kormos J, Csizér K. Age-related differences in the motivation of learning English as a foreign language: Attitudes, selves, and motivated learning behavior. Language learning. 2008;58(2):327-55.

33. Lamb M. A self system perspective on young adolescents' motivation to learn English in urban and rural settings. Language Learning. 2012;62(4):997-1023.

34. Papi M. The L2 motivational self system, L2 anxiety, and motivated behavior: A structural equation modeling approach. System. 2010;38(3):467-79.

35. Dörnyei Z. Research methods in applied linguistics. 2007.

36. Braun V, Clarke V. Using thematic analysis in psychology. Qualitative Research in Psychology. 2006;3(2):77-101.

37. Ellis R, Barkhuizen GP. Analysing learner language: Oxford University Press Oxford; 2005.

38. Lam AS. Language education in China: Policy and experience from 1949: Policy and experience from 1949: Hong Kong University Press; 2005. 